\title{
MARKA JAKO ISTOTNY ELEMENT KOMUNIKACJI MARKETINGOWEJ PRZEDSIĘBIORSTW MLECZARSKICH Z LUBELSZCZYZNY
}

\begin{abstract}
Celem niniejszego artykułu jest określenie roli marki w komunikacji marketingowej przedsiębiorstw mleczarskich $\mathrm{z}$ Lubelszczyzny $\mathrm{z}$ nabywcami finalnymi oraz struktury zachowań zakupowych nabywców finalnych ze względu na kryterium marki. W opracowaniu zaprezentowano znaczenie marki wśród pozostałych elementów zamieszczonych na opakowaniu produktu mleczarskiego na podstawie badań ankietowych oraz nieustrukturalizowanych wywiadów uzupełniającychprzeprowadzonychwśród nabywców finalnych $\mathrm{z}$ terenu województwa lubelskiego. Do opracowania danych pierwotnych uzyskanych $\mathrm{z}$ badań ankietowych wykorzystano między innymi analizę czynnikowąktórej główne zastosowania można sprowadzić do redukcji liczby zmiennych stanowiących dane pierwotne uzyskane $\mathrm{z}$ badań ankietowych oraz wykrywania struktur $\mathrm{w}$ związkach między tymi zmiennymi. .Przedstawiono ponadto specyfikę zachowań zakupowych nabywców finalnych ze względu na kryterium marki, w tym zagadnienia związane ze strategią marki, nazwą marki, logo marki oraz lojalnością respondentów. $\mathrm{Na}$ podstawie przeprowadzonych badań określono równieżrolę marki $\mathrm{w}$ komunikacji marketingowej przedsiębiorstw mleczarskich mających swoją siedzibę na terenie województwa lubelskiego. Marka okazała się jednym z istotnych elementów komunikacji marketingowej wpływających na decyzje respondentów związane z nabywaniem produktów mleczarskich z Lubelszczyzny.Niestety dość duża liczba ankietowanych, dopiero biorąc udział w omawianych badaniach, dowiedziała się o istnieniu niektórych marek producentów i wytwarzanych przez nich produktów.Można zatem stwierdzić, że w wypadku tych przedsiębiorstw mleczarskich występuje wyraźna luka informacyjna zwiększająca dystans marketingowy pomiędzy producentami a respondentami, którą ci pierwsi powinni przynajmniej zmniejszyć.

Słowa kluczowe: marka, produkty mleczarskie, przedsiębiorstwa mleczarskie, komunikacja marketingowa
\end{abstract}

\section{WPROWADZENIE}

Rola marki na rynku produktów spożywczych jest znacząca i wynika przede wszystkim z tego, że wizerunek marki istotnie oddziałuje na postrzeganie firmy i jej produktów przez nabywców finalnych ${ }^{2}$. Marka stanowi bowiem dla nich określoną gwarancję jakości oraz jej niezmienności.

\footnotetext{
${ }^{1}$ Dr Anna Iwanicka, Katedra Ekonomii i Zarządzania, Uniwersytet Przyrodniczy w Lublinie, ul. Akademicka 13, 20-950 Lublin, tel. (0-81) 46105 61, e-mail: annaiwanicka@o2.pl

2 Nabywca finalny na rynku dóbr konsumpcyjnych rozumiany jest jako osoba fizyczna, odgrywająca rolę ostatecznego odbiorcy produktu finalnego.
} 
W literaturze przedmiotu z zakresu kształtowania marki z reguły jej definicje podzielić można na dwie grupy ${ }^{3}$ :

1) marka traktowana jako zbiór korzyści będących sumą wartości produktu oraz pewnej dodatkowej wartości z nim związanej,

2) marka utożsamiana $\mathrm{z}$ pewną wartością dodaną do produktu $\mathrm{z}$ pominięciem samego wyrobu.

$\mathrm{Na}$ rynku produktów żywnościowych ze względu na bardzo dużą liczbę występujących marek podstawową funkcją marki jako elementu komunikacji marketingowej jest przede wszystkim możliwość wyróżnienia się wśród marek konkurencyjnych oraz zaistnienia w świadomości nabywców finalnych. Spełnienie tych funkcji wymaga jednak zastosowania przez przedsiębiorstwo kilku podstawowych reguł, do których należy zaliczyć ${ }^{4}$ :

- orientację na nabywcę finalnego, co oznacza, że marka powinna być stworzona dla określonej grupy odbiorców;

- konsekwencję, co oznacza, że produkt oznaczony daną marką powinien cechować się stałością pod względem smaku, składu, jakości i trwałości;

- szeroką dostępność, co oznacza, że nabywcy oczekują powszechnej dostępności produktów oferowanych pod daną marką, niezależnie od rodzaju placówki detalicznej;

- wyraźne odróżnianie się, co oznacza, że nabywcy powinni bez trudu rozpoznać i znaleźć produkt określonej marki w miejscu zakupu;

- ciagge doskonalenie, co oznacza, że ze względu na ciągłe zmiany preferencji nabywców konieczne staje się stałe doskonalenie produktów prowadzone na podstawie komunikacji z nimi.

W wypadku produktów spożywczych, oprócz oceny elementów rzeczywistych (funkcjonalnych), takich jak walory organoleptyczne, wartość odżywcza czy opakowanie, nabywca finalny bardzo często ocenia wizerunek danego producenta i jego produktów za pomocą cech nieuchwytnych, odnoszących się jedynie do sfery doznań emocjonalnych. Tym bardziej utrudnia to komunikację z punktu widzenia przedsiębiorstwa. Marka w odniesieniu do produktów żywnościowych może być zatem zdefiniowana jako „obietnica jakości, stałości składu, cech organoleptycznych i określonego poziomu ceny"5.

Dynamiczny rozwój branży mleczarskiej na przestrzeni ostatnich kilkunastu lat $\mathrm{w}$ Polsce powoduje, że posiadanie znanej i rozpoznawalnej marki warunkuje większą atrakcyjność produktów mleczarskich. Mniejsi producenci muszą ponadto konkurować z wielozakładowymi polskimi przedsiębiorstwami oraz koncernami międzynarodowymi, co w dużej mierze wynika z postępujących procesów globalizacji ${ }^{6}$. Jednostki te dysponują bardzo silnymi markami, wśród których wymienić można Hochland (w tym także Almette i Valbon), Danone (Aktivia, Actimel), Arla Foods, Zott (Jogobella) oraz Mlekpol (Łaciate, Milko) czy Mlekovita. Mniejsze przedsiębiorstwa mające często ograniczone

\footnotetext{
${ }^{3}$ A. Baruk, Nabywcy finalni jako podmioty marketingowego oddziatywania, Wydawnictwo „Dom Organizatora", Torun 2008, s. 104.

${ }^{4}$ M. Jeznach, Podstawy marketingu żywności, Wydawnictwo SGGW, Warszawa 2007, s. 39.

${ }^{5} \mathrm{H}$. Górska-Warsewicz, Perspektywy rozwoju marek $w$ sektorze żywnościowym $w$ Polsce, ,Zeszyty Naukowe SGGW. Problemy Rolnictwa Światowego" XX/5 (2008), s. 8.

${ }^{6}$ D.E. Staszczak, Globalizacja. Zbiorowa hegemonia mocarstw i korporacji transnarodowych a globalny marketing, Wydawnictwo A. Marszałek,Torun 2007, s. 7-18, 91-142.
} 
możliwości działań promocyjnych mogą zatem komunikować się z rynkiem poprzez rozpowszechnianie marki na rynkach regionalnych w celu zdobycia licznego grona lojalnych klientów.

Z punktu widzenia przedsiębiorstwa marka ma olbrzymi potencjał, często bowiem decyduje o rynkowej wartości firmy, przewyższając nawet swoją wartością wartość składników materialnych. Z kolei dla nabywców finalnych to właśnie marka ma bardzo często decydujący wpływ przy wyborze konkretnego produktu i/lub rezygnacji z innego wyrobu. Oddziałuje ona na nabywców finalnych zarówno w punkcie sprzedaży, jak i podczas wszelkich form komunikacji firmy z klientami, na przykład za pomocą narzędzi promocji.

Celem niniejszego opracowania jest określenie roli marki w komunikacji marketingowej przedsiębiorstw mleczarskich z Lubelszczyzny z nabywcami finalnymi oraz struktury zachowań zakupowych nabywców finalnych ze względu na kryterium marki.

\section{CHARAKTERYSTYKA BADAŃ}

Przeprowadzono pogłębione badania ankietowe oraz nieustrukturalizowane wywiady uzupełniające wśród nabywców finalnych $\mathrm{z}$ województwa lubelskiego. Badania przeprowadzono od czerwca do września 2009 roku wśród 900 mieszkańców z Lubelszczyzny. Badania miały charakter bezpośredni, wymagający osobistego kontaktu badacza z badanymi podmiotami. Liczebność badanej populacji ustalono na podstawie studiów literaturowych oraz konsultacji z ekspertami. Dobór próby do badań dokonano w sposób celowy, przy czym podstawowym kryterium doboru była przynależność do grupy osób, które deklarowały dokonywanie zakupów produktów mleczarskich co najmniej jednej prezentowanej marki (spośród jedenastu marek mleczarni $\mathrm{z}$ terenu województwa lubelskiego). Do analizy zakwalifikowano 714 poprawnie wypełnionych kwestionariuszy ankiet.

W badanej populacji $65,7 \%$ stanowiły kobiety, 34,3\% zaś mężczyźni. Ponad 47\% badanej populacji to osoby w wieku do 35 lat, z czego największą część reprezentowały osoby 26-35 lat, z kolei ponad 35\% stanowili ankietowani w wieku 36-55 lat, pozostała część badanych miała powyżej 55 lat. W wypadku prawie $27 \%$ respondentów miesięczny dochód netto na 1 osobę w gospodarstwie domowym mieścił się w przedziale 901-1300 zł, dla 23,2\% badanych zaś wynosił on 1301-2000 zł. Bardzo niski poziom miesięcznego dochodu netto na jedną osobę (do 400 zl) zadeklarowało 3,5\% respondentów. Prawie 30\% ankietowanych legitymowało się wykształceniem średnim, $58 \%$ zaś wyższym, $7 \%$ licencjackim, pozostali zawodowym lub podstawowym. Ponad 60\% respondentów pracowało najemnie, $15 \%$ nie pracowało, nieco ponad $8 \%$ prowadziło własną firmę, a pozostali uczyli się lub zajmowali się własnym gospodarstwem domowym.

Do opracowania danych pierwotnych uzyskanych z badań ankietowych wykorzystano między innymi analizę czynnikową, której główne zastosowania można sprowadzić do redukcji liczby zmiennych stanowiących dane pierwotne uzyskane $\mathrm{z}$ badań ankietowych oraz wykrywania struktur w związkach między tymi zmiennymi. Do wyodrębnienia czynników zastosowano metodę głównych składowych, przy czym istotne było określenie ich liczby. W tym celu wykorzystano technikę kryterium Kaisera polegająca na 
pozostawieniu tylko tych czynników, które mają wartości własne większe od 1. Rotację czynników wykonano metodą znormalizowanej varimax ${ }^{7}$.

\section{STRUKTURAPREFERENCJI NABYWCÓW FINALNYCH ZE WZGLEDU NA KRYTERIUM MARKI PRZEDSIĘBIORSTWA MLECZARSKIEGO I JEGO PRODUKTÓW}

W celu określenia roli marki wśród pozostałych elementów zamieszczonych na opakowaniu produktu mleczarskiego ankietowanym zaprezentowano zestaw elementów opakowania, które mogą być brane pod uwagę podczas dokonywania zakupów produktów mleczarskich zgromadzonych na podstawie wyników badań pilotażowych i poproszono o nadanie im konkretnych wag w skali $0-4^{8}$.

W wyniku redukcji liczby zmiennych określających elementy opakowań produktów mleczarskich wpływających na decyzje zakupowe respondentów opisano pięć grup czynników. W tabeli 1 zaprezentowano wyniki analizy czynnikowej w postaci wartości ładunków czynnikowych oraz ich interpretację na podstawie wskazań wszystkich respondentów. Wyodrębniono pięć składowych głównych, które wyjaśniają 66,6\% zmienności ogólnej.

Oznacza to, że ankietowani, podejmując decyzję zakupowa, w zakresie w jakim decyzja ta warunkowana była samym opakowaniem produktu, kierowali się w przeważającej mierze cechami występującymi w ramach tych pięciu składowych głównych, wśród których marka okazała się jednym z istotnych elementów wpływających na decyzje respondentów związane $\mathrm{z}$ nabywaniem produktów mleczarskich.

Wyniki badań wskazały ponadto, że ankietowani, którzy uzależniali wybór konkretnego produktu mleczarskiego od jego marki, utożsamiali markę producenta $\mathrm{z}$ marką produktu, co zdaniem autorki można tłumaczyć typem strategii marki stosowanej przez producentów z Lubelszczyzny. Wniosek ten potwierdzają również wyniki badań dotyczące preferowanych przez respondentów strategii marek produktów mleczarskich.

Tabela 1. Interpretacja składowych głównych uzyskanych dla grupy zmiennych określających cechy opakowań produktów mleczarskich wpływające na decyzje zakupowe respondentów.

\begin{tabular}{|c|c|c|c|c|c|}
\hline $\begin{array}{l}\text { Skladowe } \\
\text { glówne }\end{array}$ & Zmienne & $\begin{array}{l}\text { Wartość } \\
\text { ladunków }\end{array}$ & $\begin{array}{c}\text { Wartośćc } \\
\text { własna } \\
\text { składowej } \\
\text { glównej }\end{array}$ & $\begin{array}{c}\text { Ogół } \\
\text { wartości } \\
\text { wlasnych } \\
(\%)\end{array}$ & $\begin{array}{c}\text { Skumulo } \\
\text { wanewartości } \\
\text { własne (\%) }\end{array}$ \\
\hline $\begin{array}{l}\text { 1. } \\
\text { Informacje } \\
\text { nieobligatoryj } \\
\text { ne }\end{array}$ & $\begin{array}{l}\text { Informacja o } \\
\text { adresie strony } \\
\text { internetowej } \\
\text { Informacja o }\end{array}$ & $\begin{array}{l}0,818881 \\
0,635542 \\
0,849172 \\
0,748187\end{array}$ & 6,284752 & 33,07764 & 33,07764 \\
\hline
\end{tabular}

7 Analiza czynnikowa jako metoda redukcji danych, http://www.statsoft.pl/ textbook/stfacan.html\#index(dostęp: 2.02.2012) oraz A. Sokołowski, A. Sagan, Przykłady stosowania analizy danych $w$ marketingu $i$ badaniu opinii publicznej, http://www.statsoft.pl/czytelnia/marketing/adwmarketingu.html\#wymiarowosci (dostęp: 2.02.2012). ${ }^{8} 0$ oznaczało czynnik całkowicie nieważny, 1 - mało ważny, 2 - średnio ważny, 3 - ważny, 4 zaś bardzo ważny. 


\begin{tabular}{|c|c|c|c|c|c|}
\hline & $\begin{array}{l}\text { cenie } \\
\text { rekomendowane } \\
\text { j } \\
\text { Informacja o } \\
\text { infolinii } \\
\text { Informacja o } \\
\text { systemie } \\
\text { HACCP } \\
\text { Informacja o } \\
\text { SZJ zgodnym z } \\
\text { normą PN-EN } \\
\text { ISO 9001:2009 }\end{array}$ & 0,718098 & & & \\
\hline $\begin{array}{l}2 . \\
\text { Wygląd } \\
\text { zewnętrzny } \\
\text { opakowania }\end{array}$ & $\begin{array}{l}\text { Kolorystyka } \\
\text { Kształt } \\
\text { Oryginalny } \\
\text { ogólny wygląd } \\
\text { zewnętrzny } \\
\text { opakowania } \\
\text { Szata graficzna }\end{array}$ & $\begin{array}{l}0,828433 \\
0,824028 \\
0,794380 \\
0,846266\end{array}$ & 2,201422 & 11,58643 & 44,66407 \\
\hline $\begin{array}{l}\text { 3. } \\
\text { Wizerunek } \\
\text { marki }\end{array}$ & \begin{tabular}{|l|} 
Marka \\
producenta \\
Marka \\
produktu
\end{tabular} & $\begin{array}{l}\mathbf{0 , 8 4 9 5 2 0} \\
0,827309\end{array}$ & 1,877143 & $\mathbf{9 , 8 7 9 7 0}$ & $\mathbf{5 4 , 5 4 3 7 7}$ \\
\hline $\begin{array}{l}4 . \\
\text { Składowa } \\
\text { związana z } \\
\text { zależnością } \\
\text { pomiędzy } \\
\text { wielkością } \\
\text { opakowania a } \\
\text { jego } \\
\text { późniejszym } \\
\text { wykorzysta } \\
\text { niwy }\end{array}$ & $\begin{array}{l}\text { Możliwość } \\
\text { późniejszego } \\
\text { wykorzystania } \\
\text { Wielkość } \\
\text { jednostkowa } \\
\text { opakowania }\end{array}$ & $\begin{array}{l}0,628353 \\
0,623438\end{array}$ & 1,183007 & 6,22635 & 60,77012 \\
\hline $\begin{array}{l}5 . \\
\text { Ekologia }\end{array}$ & $\begin{array}{l}\text { Ekologiczność } \\
\text { (szkodliwość } \\
\text { opakowania dla } \\
\text { środowiska) } \\
\text { Materiał, z } \\
\text { którego } \\
\text { wykonano } \\
\text { opakowanie }\end{array}$ & $\begin{array}{l}0,827215 \\
0,700872\end{array}$ & 1,118452 & 5,88659 & 66,65671 \\
\hline
\end{tabular}

Źródło: opracowanie własne na podstawie wyników przeprowadzonych badań ankietowych 
Ponad połowa ankietowanych preferowała właśnie strategię marki produktu wspartej marką producenta. W ramach tej strategii przedsiębiorstwa mleczarskie z Lubelszczyzny stosowały także strategię marki parasola, gdzie pod jedną marką oferowane były jogurty, kefiry, maślanki i ewentualnie mleko. Na drugim miejscu pojawiła się z kolei strategia marki firmowej polegająca na nadawaniu tej samej marki (producenta) wszystkim produktom. Taką strategię stosowały najmniejsze Spółdzielnie z terenu województwa lubelskiego, nadając produktom jedynie nazwę będącą jednocześnie nazwą ich producenta wraz z określoną kategorią produktu. Można zatem wnioskować, że ankietowani, udzielając odpowiedzi na to pytanie, sugerowali się podejmowanymi w tym zakresie faktycznymi działaniami producentów z terenu Lubelszczyzny. Badane przedsiębiorstwa mleczarskie w bardzo ograniczonym zakresie stosowały strategię marki indywidualnej, dlatego też prawdopodobnie wskazało ją jedynie około $10 \%$ osób.

Ciekawe wnioski można także wyciągnąć na podstawie wyników badań dotyczących wizerunku marki produktów $\mathrm{w}$ związku $\mathrm{z}$ nadawaniem im konkretnych nazw. Respondentów zapytano zatem o preferowane nazwy marekproducentów oraz wytwarzanych przez nich produktów mleczarskich. Dokonano ponadto oceny lojalności ankietowanych wobec konkretnych marek tego typuproduktów, jak również ich reakcji na pojawienie się na rynku nowego produktu mleczarskiego.

Respondenci preferowali przede wszystkim arbitralne nazwy produktów mleczarskich odnoszące się do nazwy miejscowości, w której wytworzono dany produkt, ponieważ aż $53,4 \%$ ankietowanych wymieniło właśnie tego typu nazwę. Wśród producentów produktów mleczarskich $\mathrm{z}$ terenu województwa lubelskiego można wymienić dwóch, którzy stosowali tego typu rozwiązanie w nadawaniu nazw markom produktów. OSM z Chełma „Biomlek” wprowadziła nazwę marki „Nadbużański” sugerującą lokalizację miasta Chełm oraz nazwy marki „Bieluch” i „Bieluś” związane z legendarnym opiekunem chełmskichPodziemi Kredowych, strażnikiem ukrytych tam skarbów. Według legendy jest on duchem białego niedźwiedzia widniejącego w herbie Chełma, który stanowi zresztą logo marki wspomnianej Spółdzielni. OSM z Opola Lubelskiego stosowało z kolei nazwę marki „Nadwiślański” jako odniesienie do terenów nadwiślańskich wokół tego miasta.

Znaczna część badanych (24,8\%) wybierała nazwy opisowe, często będące nazwami sugestywnymi, składające się $\mathrm{z}$ kilku słów, sugerujące jednocześnie konkretne właściwości lub korzyści funkcjonalne produktu mleczarskiego. W tym wypadku doskonałym przykładem zastosowania tego typu nazwy marki jest „Mleko na 5+" wprowadzona przez SM z Radzynia Podlaskiego „Spomlek” sugerująca konkretne właściwości produktu, związane z hasłem ,Żyj na 5+”. Innym przykładem jest nazwa marki mleka „Twoje zdrowie” OSM Krasnystaw.

Odpowiednio $14 \%$ oraz $12,5 \%$ ankietowanych preferowało nazwy abstrakcyjne, czyli wymyślone przez producenta typu „Cezar”, „Jowisz”, „Mars” - SM Ryki, „Biedronka”, „Dublet” - OSM Michów oraz nazwy zdrobniałe typu „Joguś” - OSM Krasnystaw.

W wypadku nazw marek producentów wyrobów mleczarskich największa część respondentów $(46,4 \%)$ preferowała nazwę producenta stanowiącą nazwę miejscowości, $\mathrm{W}$ której zlokalizowana była spółdzielnia mleczarska. Wśród badanych jedenastu przedsiębiorstw mleczarskich aż dziewięć posługiwało się tego typu nazwą, dwa zaś stosowały nazwę związaną z rodzajem prowadzonej przez siebie działalności („Biomlek”, „Spomlek”). Mimoże nazwę marki sugerującą rodzaj działalności preferowało 10,5\% respondentów, obie wymienione nazwy marek producentów ankietowani bardzo dobrze 
kojarzyli z miejscem ich lokalizacji, czyliChełmem i Radzyniem Podlaskim, najprawdopodobniej zewzględuna długiestosowanie jednocześnie nazw stanowiących nazwy miejscowości, w których są zlokalizowani ci producenci, oraz nazw sugerujących rodzaj ich działalności. OSM z Michowa poza stosowaniem nazwy stanowiącej nazwę miejscowości, w której jest zlokalizowana, dodatkowo posługiwała się nazwą sugerującą jej lokalizację, czyli nazwą marki „Michowianka”.

Bardzo zbliżona część ankietowanych preferowała logo przedsiębiorstwa mleczarskiego stanowiące jego nazwę zapisaną w charakterystyczny sposób (odpowiednia wielkość, krój, kolorystyka i tło liter) oraz logo będące symbolem bezpośrednio informującym o cechach produktu, jego przeznaczeniu, specjalizacji, korzyściach, które można odnieść dzięki jego konsumpcji itp. Wśród badanych przedsiębiorstw większość stosowała drugie z wymienionych rozwiązań (np. w postaci herbu miasta). Dla 27,3\% ankietowanych kwestia ta nie miała większego znaczenia. Można zatem powiedzieć, że preferencje badanych dotyczące graficznej formy marki prawdopodobnie były uzależnione od innych czynników, chociażby okresu obecności danej marki na rynku czy jej kolorystyki itp.

Bardzo interesująca okazała się ocena lojalności respondentów wobec konkretnych marek produktów mleczarskich. Aż $61,2 \%$ ankietowanych często, a 21,3\% zawsze wybierało produkty mleczarskie tych samych, wypróbowanych marek. Jak wynika $\mathrm{z}$ przeprowadzonych badań, zazwyczaj lojalność ta dotyczyła trzech lub czterech i więcej wybranych producentów.

Należy jednak zaznaczyć, że niekiedy lojalność nabywców finalnych wobec konkretnych marek produktów mleczarskich zostaje poddana próbie, zwłaszcza w sytuacji pojawienia się na rynku całkiem nowego produktu mleczarskiego. W badaniach wykazano, iż 38,5\% respondentów rzadko, a 27,5\% często dokonywało zakupów pojawiających się na rynku nowości. W wypadku zaś $13,3 \%$ ankietowanych decyzja zakupowa była poprzedzana zebraniem jak największej ilości informacji o nowym produkcie, przede wszystkim z prasy, radia, TV, podczas degustacji i od znajomych.

\section{ROLA MARKI W KOMUNIKACJI MARKETINGOWEJ PRZEDSIĘBIORSTW MLECZARSKICH Z LUBELSZCZYZNY Z NABYWCAMI FINALNYMI}

Zdecydowana większość respondentów oceniła poziom znajomości marek produktów mleczarskich pochodzących $\mathrm{z}$ terenu województwa lubelskiego wśród nabywców finalnych jako dobry (41,9\% wskazań) i zadowalający (34,2\%). Jednak wyniki pogłębionych badań pokazały, że oceny te nie odzwierciedlały w pełni stanu faktycznego.

OSM Krasnystaw, SM „Spomlek” Radzyń Podlaski oraz SM „Biomlek” Chełm to marki producentów z terenu województwa lubelskiego, których produkty były najczęściej wybierane przez respondentów. Ponad 90\% badanych kupowało produkty marki OSM Krasnystaw oraz odpowiednio 56,5\% osób w wypadku SM „Spomlek” i 51,8\% osób w wypadku SM „Biomlek” deklarowało, że kupowało wyroby tych producentów. Na podstawie wyników badań stwierdzono ponadto, iż w wypadku takich marek, jak SM Biała Podlaska, TSM Tomaszów Lubelski oraz OSM Janów Lubelski, istniał największy odsetek osób (odpowiednio 45,9\%, 44,8\%, 43,7\%) jednoznacznie deklarujących, nie kupują jakichkolwiek produktów mleczarskich tych producentów. 
Ponadto również w wypadku tych właśnie producentów największa część respondentów nie była w zasadzie pewna, czy faktycznie dokonywała, czy też nie ich zakupu. Wyraźnie zauważalną przyczyną nienabywania produktów mleczarskich konkretnych marek producentów był ponadto brak ich aktywności w zakresie podejmowania działań promocyjnych.

Najprawdopodobniej ankietowani byliby zatem skłonni do zakupu produktów mleczarskich innych niż dotychczas marek producentów, jeżeli w ogóle wiedzieliby o ich istnieniu, co z kolei bezpośrednio wiąże się z koniecznością zwiększenia dostępności ich wyrobów.

Ankietowanych zapytano ponadto o dokonywanie zakupu produktów mleczarskich konkretnych marek wytwarzanych przez analizowane przedsiębiorstwa oraz zidentyfikowanie przedsiębiorstwa, w którym zostały one wyprodukowane. Wśród 49 nazw marek produktów mleczarskich pochodzących $\mathrm{z}$ terenu województwa lubelskiego ${ }^{9}$ najczęściej kupowany okazał się joguś (OSM Krasnystaw), bieluch (SM „Biomlek”), rycki edam (SM Ryki) oraz ser radamer (SM ,Spomlek”).

Podczas zakupów produktów mleczarskich dla niektórych ankietowanych w większym stopniu ważniejsza była jednak marka produktu niż marka jego producenta, ponieważ jedynie w przypadku nazwy marki joguś aż 65,3\% ankietowanych poprawnie zidentyfikowało przedsiębiorstwo, z którego pochodził ten produkt. W wypadku nazwy marki bieluch, rycki edam oraz radamer zdecydowanie mniejsza część badanych (odpowiednio 36,4\%, 36,6\% oraz 12,2\%) prawidłowo wskazała właściwego producenta. W wypadku nazwy marki rycki Edam mogło być spowodowane podobieństwem nazwy marki produktu i nazwy marki producenta, podobnie jak w wypadku sera edam michowski (37,4\% wskazań). Dla pozostałych najczęściej kupowanych przez respondentów produktów mleczarskich odsetek ankietowanych poprawnie identyfikujących nazwę marki i ich producenta również był stosunkowo niewielki i kształtował się w granicach od $0 \%$ w wypadku sera liliput z TSM Tomaszów Lubelski do $18,2 \%$ w wypadku serka seruś z OSM Krasnystaw.

\section{PODSUMOWANIE}

Budowanie i utrzymanie zaufania nabywców finalnych do marki producenta powinno być jednym z priorytetowych celów dla przedsiębiorstw, które muszą pamiętać o często wskazywanej w literaturze zasadzie, że zaledwie kilkuprocentowy wzrost wartości tak zwanego wskaźnika retencji (czyli procentowego stosunku liczby nabywców pod koniec danego przedziału czasu do liczby nabywców na początku tego przedziału czasowego) pociąga za sobą wzrost wartości wskaźników rentowności przedsiębiorstwa aż o kilkadziesiąt procent ${ }^{10}$.

Marka okazała się jednym z istotnych elementów komunikacji marketingowej wpływających na decyzje respondentów związane z nabywaniem produktów mleczarskich z Lubelszczyzny. Marka produktu była ponadto często utożsamiana z marką jego producenta.

\footnotetext{
${ }^{9} \mathrm{~W}$ grupie tej znalazły się wszystkie produkty mleczarskie pochodzące z terenu województwa lubelskiego, którym producenci nadali konkretne nazwy (poza ogólnymi nazwami kategorii produktów)

${ }^{10}$ A. Baruk, Marketing-mix w przedsiębiorstwie, AR, Lublin 2001, s. 128.
} 
Niepokojące jest, że dość duża liczba ankietowanych, dopiero biorąc udział w omawianych badaniach, dowiedziała się o istnieniu niektórych marek producentów i ich produktów. W wypadku tych przedsiębiorstw występuje wyraźna luka informacyjna zwiększająca dystans marketingowy pomiędzy producentami a respondentami, którą ci pierwsi powinni przynajmniej zmniejszyć.

\section{LITERATURA}

[1] Analiza czynnikowa jako metoda redukcji danych, http://www.statsoft.pl/ textbook/stfacan.html\#index.

[2] Baruk A., Marketing-mix w przedsiębiorstwie, AR, Lublin 2001.

[3] Baruk A., Nabywcy finalni jako podmioty marketingowego oddziaływania, Wydawnictwo „Dom Organizatora”, Torun 2008.

[4] Górska-Warsewicz H., Perspektywy rozwoju marek $w$ sektorze żywnościowym $w$ Polsce, „Zeszyty Naukowe SGGW. Problemy Rolnictwa Światowego” XX/5 (2008).

[5] Jeznach M., Podstawy marketingu żywności, Wydawnictwo SGGW, Warszawa 2007.

[6] Sokołowski A., Sagan A., Przykłady stosowania analizy danych w marketingu $i$ badaniu opinii publicznej:

[7] http://www.statsoft.pl/czytelnia/marketing/adwmarketingu.html\#wymiarowosci.

[8] Staszczak D.E.,Globalizacja. Zbiorowa hegemonia mocarstw $i$ korporacji transnarodowych a globalny marketing, Wydawnictwo A. Marszałek, Toruń 2007.

\section{BRAND AS AN IMPORTANT ELEMENT OF MARKETING COMMUNICATION OF DIARY PLANTS IN THE LUBLIN AREA}

The article is aimed at defining the role of a brand in marketing communication between diary plants and final purchasers. An in-depth questionnaire survey and complementary free interviews were conducted among final purchasers in the Lublin area. Factor analysis was used to compile primary data from the survey. On the basis of the research carried out, the significant of the brand have been presented among the remaining elements included on the package of dairy products. The article also presents the structure of consumer behavior of final purchasers, with the brand criterion taken into consideration, including the notions connected with the brand strategy, the name of brand, the logo and loyalty of the respondents. On the basis of the research carried out the article also presents the role of a brand in marketing communicationconcern diary plants in the Lublin area. The brand turned out to be one of the crucial factors marketing communication. It largely influenced the respondents' decisions that concerned buying dairy products from Lublin region. Unfortunately, it was only when the respondents took part in doing the research the majority of them found out about the existence of some companies' brands and the products made by them. One cantherefore claim that as far as these dairy companies are concerned, there is a significant information gap which deepens the marketing distance between producers and respondents.

Keywords: brand, dairy products, dairy companies, marketing communication.

DOI:10.7862/rz.2013.hss.3

Tekst złożono w redakcji: grudzień 2012.

Przyjęto do druku: czerwiec 2013. 